\title{
TATA KELOLA GAMBARAN PERENCANAAN MEDIA PEMBELAJARAN BERBASIS AUDIO VISUAL PADA MATA PELAJARAN BAHASA INDONESIA DI SMA NEGERI I LAROMPONG KABUPATEN LUWU
}

\author{
Tasdin Tahrim \\ Institut Agama Islam Negeri Palopo \\ E-mail: tasdintahrim811@gmail.com
}

\begin{abstract}
The study aimed to determine the picture of audio visual based learning media planning in Indonesian subjects. This type of research is descriptive qualitative to find the nature or experience of a person with a phenomenon that is the governance of audio visual based learning media. Data was collected through: stakeholder involvement through the planning of Larompong 1 High School learning media management. Audio Visual Based learning media governance is obtained through two data sources namely informants and documents. Data collection techniques through interviews, observation, documentation and focus group discussions. The results of the study show: The governance of audio visual based learning media planning begins with the selection of instructional media tailored to the material and learning objectives in the RPP with the principles of using audio-visual media and refers to the Minimum Completeness Criteria. Students who get the KKM value exceeds the KKM value that has been set by the school means that the student has been able to study thoroughly, conversely if students who get the KKM value is smaller and the KKM value that has been set by the school then the student is said to have not finished learning. Students will be given remedial services by subject teachers and for those who have met the KKM, then given enrichment.
\end{abstract}

Keywords: Audio Visual Learning Management

\begin{abstract}
Abstrak
Penelitian ini bertujuan mengetahui gambaran perencanaan media pembelajaran berbasis audio visual pada mata pelajaran bahasa Indonesia. Jenis Penelitian ini adalah deskriptif kualitatif untuk menemukan sifat atau pengalaman seseorang dengan suatu fenomena yaitu tata kelola gambaran media pembelajaran Berbasis Audio Visual . Data dikumpulkan melalui : keterlibatan stakeholder melalui perencanaan pengelolaan media pembelajaran SMA 1 Larompong. Tata kelola media pembelajaran Berbasis Audio Visual diperoleh melalui dua sumber data yaitu informan dan dokumen. Teknik pengumpulan data melalui wawancara, observasi, dokumentasi dan focus discussion group. Hasil Penelitian menunjukkan: Tata kelola gambaran perencanaan media pembelajaran berbasis audio visual diawali dengan pemilihan media pembelajaran disesuaikan dengan materi dan tujuan pembelajarannya dalam RPP dengan prinsip-prinsip penggunaan media audio-visual serta mengacu pada Kriteria Ketuntasan Minimal. Siswa yang memperoleh nilai KKM melebihi dari nilai KKM yang telah ditetapkan oleh sekolah berarti siswa tersebut sudah dapat belajar dengan tuntas, sebaliknya jika siswa yang memperoleh nilai KKM lebih kecil dan nilai KKM yang telah ditetapkan oleh sekolah maka siswa tersebut dikatakan belum tuntas belajarnya. Siswa tersebut akan diberikan layanan remedial oleh guru mata pelajaran dan bagi yang telah memenuhi KKM, maka diberikan pengayaan.
\end{abstract}

Kata Kunci: Manajemen Pembelajaran Audio Visual

Volume 4, No.1, April 2019 


\section{8 | Tasdin Tahrim}

\section{PENDAHULUAN}

Pendidikan merupakan proses perubahan tingkah laku peserta didik agar menjadi manusia dewasa yang mampu hidup mandiri sebagai anggota masyarakat dalam lingkungan sekitar dimana individu itu berada. Pendidikan tidak hanya sekedar mengembangkan intelektual semata, akan tetapi menekankan pula pada proses pembinaan kepribadian peserta didik secara menyeluruh sehingga bisa menjadi dewasa dan mengetahui status serta perannya di masyarakat.

Menurut ayat (1) pasal 37 UU No. 20 Tahun 2003 tentang "Sistem Pendidikan Nasional"1 kurikulum yang termasuk pada pendidikan dasar wajib memuat 10 pelajaran yang salah satunya adalah Bahasa Indonesia.

Pendidikan bahasa Indonesia di sekolah lanjutan tingkat atas bertujuan mengembangkan kemampuan berbahasa Indonesia siswa sesuai dengan fungsi bahasa sebagai wahana berpikir dan wahana berkomunikasi untuk mengembangkan potensi intelektual, emosional dan sosial.Bahasa sangat fungsional dalam kehidupan manusia, karena selain merupakan alat komunikasi yang paling efektif, berpikir pun menggunakan bahasa.

Untuk mencapai tujuan kurikulum pembelajaran pada proses belajar mengajar maka perlu didukung media dan bahan ajar yang baik yaitu bahan ajar yang mampu menarik minat siswa, sesuai dengan zaman dan tidak menyimpang dari kurikulum. Penyajian materi pelajaran pada pokok bahasan dengan menggunakan LCD diharapkan menarik minat siswa, membangkitkan gairah siswa untuk mempelajari kembali materi yang disajikan melalui multi media (teks, citra, audio, video) materi yang disajikan dengan berbagai warna dan gambar yang sangat menarik dan sebagainya. Peneliti menemukan bahwa proses mengajar secara umum masih menggunakan metode ceramah dengan bantuan media buku dan white board, keberadaan media pembelajaran audio-visual kerap tidak dipergunakan. ${ }^{2}$

Penggunaan metode dan strategi secara optimal didukung oleh media yang telah dikembangkan untuk membangkitkan motivasi siswa dalam belajar Bahasa Indonesia. Melalui media yang telah dikembangkan siswa dapat menggunakaan secara optimal alat indera yang dimilikinya. Semakin banyak alat indera yang digunakan oleh siswa maka sesuatu yang dipelajari akan makin mudah diterima dan diingat, akhirnya media dapat memotivasi siswa untuk belajar lebih baik.

Pengelolaan ini dilakukan mulai dari perencanaan, pengadaan, pemeliharaan dan penataan lahan bangunan, perlengkapan sekolah secara

\footnotetext{
1 ayat (1) pasal 37 UU No. 20 Tahun 2003 tentang "Sistem Pendidikan Nasional"

2 Andre, Rinanto. Peranan Media Audio Visual dalam Pendidikan. (Yogyakarta: Yayasan Kanesius, 2004), h. 12-13
} 
tepat guna dan tepat sasaran.Media yang digunakan dalam pembelajaran dapat berupa media visual, audio maupun audio visual.Media, sarana dan prasarana yang digunakan hendaknya relevan dengan yang dibutuhkan dan tidak mengganggu kenyamanan siswa dalam belajar.

Seorang guru tentu saja harus dapat menerapkan media apa yang paling tepat dan sesuai untuk tujuan tertentu, penyampaian bahan tertentu, suatu kondisi belajar siswa, dan untuk penggunaan strategi atau metode yang memang telah terpilih. Berbagai jenis media pendidikan adalah penting diketahui guru, dan tentu saja akan lebih baik lagi jika guru-guru itu memilih kemampuan membuat suatu media pendidikan yang dibutuhkannya. ${ }^{3}$

Alat-alat audio visual ada faedahnya kalau yang menggunakan telah mempunyai keterampilan yang lebih yang dan memadai dalam penggunaanya, beberapa cara menggunakan alat-alat audio visual yaitu dengan adanya persiapan, pelaksanaan dan kegiatan lanjutan.

Alat pelajaran yang biasa juga disebut alat peraga ini dikenal dengan istilah media pendidikan. Guru harus memandang media pendidikan sebagai alat bantu utama untuk menunjang keberhasilan mengajar dan memperkembangkan metode-metode yang dipakainya dengan memanfaatkan media pendidikan. Ditangan gurulah alat-alat itu bermakna bagi pertumbuhan pengetahuan, keterampilan dan pembentukan sikap siswa. disamping itu guru mempunyai peran sebagai pengajar, mendidik, melatih dan mengevaluasi.

Dalam pembelajaran, siswa menggunakan asas pendidikan dan teori belajar merupakan penentu utama keberhasilan pendidikan. Pembelajaran merupakan proses komunikasi dua arah, mengajar dilakukan oleh pihak guru atau pendidik, sedangkan belajar dilakukan oleh peserta didik atau siswa.

Salah satu mata pelajaran yang menggunakan media pembelajaran audio visual di SMA Negeri 1 Larompong yaitu mata pelajaran Bahasa Indonesia. Pendidikan bahasa Indonesia bertujuan untuk mengembangkan kemampuan berbahasa Indonesia siswa sesuai dengan fungsi bahasa sebagai wahana berfikir dan berkomunikasi untuk mengembangkan potensi intelektual, emosional dan sosial. Bahasa sangat fungsional dalam kehidupan manusia, karena selain merupakan alat komunikasi yang paling efektif, berfikir pun menggunakan bahasa.

Manfaat penggunaan audiovisual meliputi : siswa dapat memperoleh persepsi yang sama dan benar dalam menerima materi pelajaran. Guru membuat siswa lebih fokus pada pembelajaran dan membantu mengigat kembali materi sehingga lebih mudah berbagi pengetahuan dan keterampilan yang telah dipelajari. Penggunaan media audio-visual dipandang tepat untuk

\footnotetext{
${ }^{3}$ Ade Koesnandar . Guru dan Media Pembelajaran. (Jurnal Teknodik, 2003) h. 8
} 


\section{0 | Tasdin Tahrim}

memberikan pemahaman yang bersifat konkret,sehingga mempermudah siswa menyerap materi yang disampaikan. Materi yang diserap selanjutnya akan disampaikan kembali oleh siswa melalui teknik berbicara. ${ }^{4}$

Berdasarkan landasan penelitian inilah, peneliti ingin mengetahui lebih jauh tentang penggunaan media audio visual, sehingga pada waktu pembelajaran Bahasa Indonesia siswa lebih giat lagi untuk belajar dengan adanya media tersebut. Dari sinilah penulis mengadakan penelitian di SMA Negeri 1 Larompong dengan judul " Tata Kelola Gambaran Perencanaan Media Pembelajaran Berbasis Audio Visual Pada Mata Pelajaran Bahasa Indonesia di SMA Negeri 1 Larompong Kabupaten Luwu".

\section{METODE}

Penelitian ini merupakan penelitian kualitatif dengan deskriptif yaitu studi yang mengeksplorasi suatu masalah secara terperinci, memiliki pengambilan data yang mendalam dan menyertakan berbagai sumber informasi. Penelitiann ini dilaksanakan di SMA Negeri 1 Larompong Kabupaten Luwu. Fokus dan Deskripsi Fokus Penelitian ini adalah sebagai berikut :

1. Tata kelola pembelajaran adalah cara atau kegiatan guru dalam merencanakan media pembelajaran audio visual pada mata pelajaran Bahasa Indonesia.

2. Media audio visual adalah segala alat yang dipakai guru dalam pelaksanaan pembelajaran bahasa Indonesia yang dapat dipandang dan didengar siswa.

3. Perencanaan media pembelajaran berbasis audio visual pada mata pelajaran Bahasa Indonesia adalah proses penetapan pekerjaan tujuan yang harus dilaksanakan oleh guru mata pelajaran Bahasa Indonesia untuk mencapai tujuan pembelajaran yang telah digariskan. ${ }^{5}$

\section{GAMBARAN PERENCANAAN MEDIA PEMBELAJARAN BERBASIS AUDIO VISUAL PADA MATA PELAJARAN BAHASA INDONESIA DI SMA NEGERI 1 LAROMPONG KECAMATAN LAROMPONG KABUPATEN LUWU}

\section{Perencanaan Media Pembelajaran}

Hasil penelitian perencanaan tata kelola media pembelajaran audio visual di SMA Negeri 1 Larompong Kecamatan Larompong Kabupaten Luwu

4 Arief S. Sadiman, dkk. Media Pendidikan, Pengertian, Pengembangan, dan. Pemanfaatannya. (Jakarta: Rajawali Press, 2009) h. 29-30

${ }^{5}$ Moleong, Lexy J. Metode Penelitian Kualitatif. (Bandung: Remaja Rosdakarya, 2011) h, 9 
menunjukkan bahwa penggunanaan media pembelajaran di SMA Negeri 1 Larompong Kecamatan Larompong, dilakukan oleh semua guru mata pelajaran yang akan mengajar tergantung dari pokok bahasan yang akan dibawakan apakah memang harus menggunakan media pembelajaran atau tidak. Dan jika harus menggunakan media, maka harus memilih media yang cocok yang dapat digunakan untuk mencapai hasil belajar sesuai dengan standar kompetensinya.

Pada mata pelajaran Bahasa Indonesia jenis media yang sering digunakan di SMA Negeri 1 Larompong Kecamatan Larompong Kabupaten Luwu adalah media pembelajaran berbasis audio visual.

\section{Tujuan Perencanaan Media Pembelajaran}

Setiap kegiatan organisasi dalam mencapai tujuan perlu perencanaan yang matang sesuai dengan tujuannya. Tujuan perencanaan adalah untuk menghindari atau setidak-tidaknya memperkecil tumpang tindih dan pemborosan (wasteful) pelaksanaan aktivitas-aktivitas pada media pembelajaran, atau dengan kata lain tujuan perencanaan adalah menentukan arah pencapaian tujuan pembelajaran dengan menggunakan mediapembelajaran berbasis audio visual.

a. Memudahkan pengawasan

Dengan adanya planning, kita dapat mengetahui penyelewengan yang terjadi karena planning merupakan pedoman dan patokan dalam melakukan suatu usaha. Agar dapat membuat perencanaan yang baik, maka manajer memerlukan data-data yang lengkap, dapat dipercaya serta aktual.

b. Kemampuan evaluasi yang teratur.

Dengan adanya planning, kita dapat mengetahui apakah usaha yang kita lakukakan sudah sesuai dengan tujuan yang ingin kita capai. Sehingga tidak terjadi under planning dan over planning.

c. Sebagai alat koordinasi.

Perencanaan dalam suatu kegiatan kadang-kadang begitu kompleks, karena untuk perencanaan tersebut meliputi berbagai bidang di mana tanpa koordinasi yang baik dapat menimbulkan benturan-benturan yang akibatnya dapat cukup parah. ${ }^{6}$

\section{Tindakan untuk Mencapai Tujuan}

Tindakan adalah menentukan langkah-langkah untuk mencapai tujuan pembelajaran dengan menggunakan media pembelajaran berbasis audio visual. Hasil penelitian tentang langkah-langkah yang diambil oleh guru Bahasa Indonesia di SMA Negeri 1 Larompong Kecamatan Larompong Kabupaten Luwu dalam pencapaian tujuan yaitu para guru SMA Negeri 1

${ }^{6}$ Sanaky, Hujair, Media Pembelajaran, (Yogyakarta:Safiria Insania Press, 2009) h, 51 


\section{2 | Tasdin Tahrim}

Larompong Kecamatan Larompong yang menggunakan media pembelajaran audio visual sebelumnya telah mengadakan persiapan mengajar sesuai dengan tujuan pembelajarannya.

Rencana pelaksanaan tata kelola pembelajaran disusun dan mengacu pada prinsip-prinsip penggunaan media audio visual sebagai sarana mendekatkan materi pelajaran dengan pengalaman siswa. Langkah selanjutnya adalah penjadwalan penggunaan media, mempersiapkan alat media yang akan digunakan, dan mempersiapkan ruangan dan siswa yang akan mendapat materi pembelajaran tersebut. Selain hal tersebut, langkalangkah lainnya yaitu memastikan ruangan yang akan digunakan dalam keadaan bersih, mengadakan pengaturan ruangan kelas yang memungkinkan siswa dapat duduk dengan rapih dan mengikuti pembelajaran dengan nyaman.

\section{Pengembangan Pemikiran}

Seiring perkembangan ilmu dan teknologi, media pembelajaran yang digunakan semakin canggih dalam proses belajar mengajar. Pentingnya mengembangkan media merupakan salah satu faktor penentu keberhasilan pembelajaran. Menyikapi hal tersebut, dalam rangka peningkatan kompetensi lulusan SMA Negeri 1 Larompong Kecamatan Larompong dalam hal penggunaan media pembelajaran audio visual kedepannya perlu adanya penambahan sarana media pembelajaran.

Karena pada saat ini media pembelajaran terutama yang menggunakan media audio visual terbatas hanya disediakan untuk masingmasing tiga kelas per angkatan, dengan jumlah kelas belajar per angkatan yaitu untuk kelas X terdiri atas 8 kelas, kelas XI terdiri atas 8 kelas, dan kelas XII terdiri atas 7 kelas.

Keberhasilan penggunaan media, tidak terlepas dari bagaimana media itu direncanakan dan dipilih dengan baik. Media yang dapat mengubah perilaku siswa (behaviour change) dan meningkatkan hasil belajar siswa tertentu, tidak dapat berlangsung secara spontanitas, namun diperlukan analisis yang komprehensif dengan memperhatikan berbagai aspek yang dapat mempengaruhi keberhasilan pembelajaran.

\section{Identifikasi Cara}

Penggunaan media pembelajaran berbasis audio visual di SMA Negeri 1 Larompong Kecamatan Larompong Kabupaten Luwu, dari identifikasi yang dilakukan, ada dua kendala atau faktor pembatas dalam pembelajaran Bahasa Indonesia yaitu pertama adalah sarana dan prasarana media belum memadai. 
Kedua keterampilan atau skill guru masih perlu ditingkatkan dalam hal pembuatan materi pelajaran yang berbasis audio visual, yang selama ini masih dominan menggunakan materi media yang sudah jadi.

\section{PENUTUP}

Berdasarkan hasil penelitian deskripsi Tata Kelola Gambaran Perencanaan Media Pembelajaran Berbasis Audio Visual pada Mata Pelajaran Bahasa Indonesia di SMA Negeri 1 Larompong Kabupaten Luwu, maka dapat disimpulkan bahwa tata kelola perencanaan media pembelajaran berbasis audio visual di SMA Negeri 1 Larompong Kecamatan Larompong Kabupaten Luwu diawali dengan pemilihan media pembelajaran disesuaikan dengan materi dan tujuan pembelajarannya dalam RPP (Rencana Pelaksanaan Pembelajaran). Salah satu prinsip penilaian pada kurikulum berbasis kompetensi pada mata pelajaran Bahasa Indonesia adalah menggunakan acuan kriteria yaitu Kriteria Ketuntasan Minimal (KKM).

\section{DAFTAR PUSTAKA}

Andre, Rinanto. Peranan Media Audio Visual dalam Pendidikan. Yogyakarta: Yayasan Kanesius, 2004.

Ade Koesnandar . Guru dan Media Pembelajaran. Jurnal Teknodik, 2003

Moleong, Lexy J. Metode Penelitian Kualitatif. Bandung: Remaja Rosdakarya, 2011.

Arief S. Sadiman, dkk. Media Pendidikan, Pengertian, Pengembangan, dan. Pemanfaatannya. Jakarta: Rajawali Press, 2009.

Sanaky, Hujair, Media Pembelajaran, Yogyakarta:Safiria Insania Press, 2009. 
74 | Tasdin Tahrim

HALAMAN INI SENGAJA DIKOSONGKAN 